\title{
Chinese Firms' Entry to Export Markets: The Role of Foreign Export Spillovers
}

\author{
Florian Mayneris and Sandra Poncet
}

\begin{abstract}
In this paper, the effect of proximity to multinational exporters on the creation of new export linkages (the extensive margin of trade) is debated. Using panel data from Chinese customs for 1997-2007, the capacity for Chinese domestic firms to begin exporting new varieties to new markets is shown to respond positively to the export activity of neighboring foreign firms. These spillovers are shown to be product and country specific. This conclusion is robust to fixed effects and instrumental variable specifications that control for both supply and demand shocks that could bias the estimations. The impact is sizable. The marginal impact of product-country-specific foreign export spillovers is five times as large as the effect of a 10 percent increase in the demand for the product in the destination country. Foreign export spillovers are also shown to be primarily limited to ordinary trade activities. Overall, our findings suggest that even for a country with an important cost-advantage such as China, there is room for initiatives from policy-makers that will diffuse best practices regarding export experience among exporters. JEL codes: F1, R12, L25
\end{abstract}

There is evidence that most of the recent growth in Chinese exports is due to foreign firms. Several studies also argue that foreign firms, which are typically engaged in processing trade activities, drive the skill content upgrading of China's manufacturing exports (Amiti and Freund 2010; Xu and $\mathrm{Lu} 2009$ ). Moreover, estimations of growth equations indicate that the income gains from export performance and export upgrading are confined to the improvements made by domestic firms. Jarreau and Poncet (2012) find that the positive association between GDP per capita growth and export sophistication at the province level is limited to ordinary export activities undertaken by domestic firms. These results, together with the results emphasized by Amiti and Freund (2010), suggest that the export activities of foreign firms in China do not matter for the economic growth of Chinese provinces once domestic exports have been

Florian Mayneris (corresponding author) is an assistant professor at the Universite catholique de Louvain and a researcher at IRES and CORE; his email address is florian.mayneris@uclouvain.be. Sandra Poncet is a professor at the Paris School of Economics - Université de Paris 1 Panthéon-Sorbonne and a scientific advisor at CEPII; her email address is sandra.poncet@cepii.fr.

We thank the editor, three anonymous referees, Matthieu Crozet, Julien Martin, Laura Rovegno, and the participants at the GSIE seminar and the Cesifo Venice Summer Institute for their helpful suggestions.

THE WORLD BANK ECONOMIC REVIEW, VOL. 29, NO. 1, pp. 150-179

doi:10.1093/wber/lht009

Advance Access Publication April 19, 2013

(C) The Author 2013. Published by Oxford University Press on behalf of the International Bank for Reconstruction and Development / THE WORLD BANK. All rights reserved. For permissions, please e-mail: journals.permissions@oup.com 
controlled for. However, although there are no direct gains from the export upgrading of foreign firms in terms of GDP per capita, there may be room for foreign firms to indirectly affect domestic firms through export spillovers. There are two channels through which export spillovers can act. Foreign firms can provide specific information on export markets that can help domestic firms to reduce their fixed export costs (e.g., information about the tastes of foreign consumers or distribution networks abroad). Foreign export spillovers can also be linked to the mutualization of fixed or variable export costs (participation in international fares, marketing, transport costs). Thus, it is worth investigating whether foreign firms in China act as export catalysts that foster the creation of new export transactions by domestic firms.

Using panel data from Chinese customs that record provincial export flows for the period 1997-2007 by product, destination country, type of firm, and type of trade, this paper shows that the capacity of Chinese domestic firms to begin exporting new products to new markets responds positively to the export activity of neighboring foreign firms. These export spillovers are found to be very specific both in terms of activity and in terms of the geography of exports. Furthermore, the effect of these export spillovers exhibits a spatial decay consistent with the spillover interpretation and is primarily limited to ordinary trade activities. Endogeneity issues are carefully addressed by introducing relevant controls and fixed effects in the benchmark regression. The estimated impact is robust to more demanding specifications in terms of fixed effects, and it resists an instrumental variable approach that uses the presence of export promotion zones interacting with product-country demand shocks as an instrument for multinational firms' exports. From a quantitative point of view, the size of the effect is not negligible. The marginal impact of the product-country-specific foreign export spillovers is five times as large as a 10 percent increase in the demand for the product in the destination country.

Beyond a mere empirical quantification, the study of export spillovers is a relevant topic from both an academic and a policy viewpoint. Indeed, with the globalization of exchanges, export performance has become an increasingly important dimension of a country's economic success. However, not all firms export, and understanding both theoretically and empirically what determines entry into export markets is a prerequisite to the design of adequate policies aimed at stimulating exports. Moreover, for a country that is very open to FDI, such as China, analyzing the role of foreign firms in the development of domestic export capabilities is crucial.

Hence, our work contributes to several strands of the literature. This work first participates in the literature on the role of the local environment in firm-level export performance. Many theoretical and empirical papers show that exporting firms represent a small fraction of active firms. Fixed and variable export costs generate selection mechanisms in export markets (e.g., Melitz 2003; Bernard and Jensen 2004; Melitz and Ottaviano 2008; Mayer and Ottaviano 2008). These costs are partly explained by the necessity of finding a distributor in the destination country, adapting products to foreign consumers' tastes, or discovering new 
sources of demand. Domestic firms might benefit from the experience of multinationals in this respect; the possible spillover channels are information externalities, cost-sharing opportunities, and mutualized actions on export markets. Krautheim (2012) provides one of the few theoretical works on export spillovers, in which proximity to other exporters is assumed to reduce the fixed export cost due to the endogenous formation of informational networks between exporting firms. Most of the literature on this topic is empirical. In a pioneering work, Aitken et al. (1997) show that the export decisions of local firms in Mexico is positively influenced by their proximity to multinational exporters. This result has been confirmed by Kneller and Pisu (2007) for UK data and by Kemme et al. (2009) for India. In contrast, Barrios et al. (2003) do not find clear evidence for these export spillovers from foreign firms in Spain, whereas Ruane and Sutherland (2005) find that the export intensity of foreign-owned enterprises is negatively correlated with the export decision and export intensity of domestic firms in Irish manufacturing, suggesting that no (and even negative) export spillovers derive from third-country export-platform FDI. This prediction bodes ill for China, where foreign firms are primarily engaged in the processing trade (i.e., the assembly of imported inputs, which are then re-exported as a final product). In the context of China, three studies investigate export spillovers emanating from foreign firms (Ma 2006; Swenson 2008; Chen and Swenson forthcoming). These papers relate the probability of exporting (or the number of new export transactions at the city or province level) to the presence of multinational firms. They find evidence of positive foreign export spillovers at the two-digit industry level (approximately 100 SITC or HS sectors).

This paper goes further in developing an understanding of the mechanisms at play in foreign export spillovers in China by exploiting data at a finer level, both in terms of the geography of exports and in terms of activities. In particular, Krautheim (2012) argues in his theoretical paper that the relevant information might be destination specific. For example, technical regulations or specific consumer tastes vary across countries. Koenig (2009) finds evidence of export spillovers from French data only when the destination dimension is taken into account. Export spillovers might also occur at a fine product category level that is more detailed than the HS2 categories, which might be highly heterogeneous. For example, in the French case, Koenig et al. (2010) show that export spillovers are magnified when they are product and destination specific (products defined at the 4-digit level). By showing that foreign export spillovers in China are product-country specific and primarily limited to ordinary trade activities, this paper opens the "black box" of these spillovers. This research is also valuable for policy-makers who are interested in tailoring fine-tuned export promotion policies based on spillovers between domestic and foreign firms. The types of actions that public authorities should favor and the type of actors upon which they should rely to promote externalities might differ depending on whether the export spillovers are specific to the exported product or to the destination country, for example. 
This paper also complements existing studies on the role of foreign firms in the evolution of Chinese exports. Beyond foreign firms' activities per se, this paper highlights the externalities that foreign firms can exert on domestic firms by stimulating the extensive margin of trade through the creation of new export transactions.

Finally, this paper contributes to the literature on the determinants of growth in China and, more generally, in countries that are very open to FDI. By showing that export externalities primarily apply to ordinary trade activities, this paper points to the limited role of export-platform activities for the promotion of Chinese firms' export performance. This result may indicate that Chinese domestic firms are less likely to internalize benefits from a foreign presence when multinationals' activities are limited to the mere assembly of previously imported inputs.

The rest of the paper is organized as follows. Section 2 describes the data, our empirical approach, and our measure of export spillovers. Section 3 presents and discusses our baseline results, and Section 4 concludes the paper.

\section{DATA AND INDICATORS}

\section{Trade Data Sources}

The data used in this study come from Chinese Customs and provide export flows aggregated by province, year, product, and destination country over the 1997-2007 period. $^{1}$ We reaggregate the original eight-digit-level data into HS4-level data (more than 1,200 product lines). An interesting feature of this dataset is that it allows us to identify whether the export flows emanate from domestic or foreign firms ${ }^{2}$ and whether they correspond to processing trade or to ordinary trade. ${ }^{3}$ The processing trade includes all trade flows by firms operating in the assembly sector; that is, firms that import and process inputs in China and

1. We do not have firm-level data, but we believe that province/firm-type/trade-type/product/ destination country data are suitable for the investigation of micro-phenomena such as export spillovers. The information that we have is very detailed. Feenstra and Hanson (2005) argue, for example, that their city/firm-type/trade-type/product/destination country dataset approaches the precision of a firm-level dataset. Moreover, with firm-level data, we would have information on the overall size or productivity of the firm, but we would lack information on the firm/product-specific ability. Finally, we have over four million observations for our regressions. For the analysis of the determinants of entry on export markets, firm-product-destination country data would hardly be tractable.

2. The data are separately reported by firm type, including foreign-owned enterprises, Sino-foreign joint ventures, collective enterprises, private enterprises, and state-owned enterprises. The first two categories are considered foreign firms, and the other categories are considered domestic firms. Unreported regressions, available upon request, show that the results hold when restricting domestic firms to state-owned or private firms. In addition, the foreign export spillovers appear to emanate similarly from both fully-foreign and joint-venture firms.

3. The data also refer to a third category ("Others") that groups other flows, such as aid, border trade, and consignment, together representing less than 1 percent of the total trade value per year. When considering the processing/ordinary trade distinction, this category is dropped. 
then re-export the final products abroad. Firms engaged in this type of activity might be less embedded in their local environment and might consequently generate fewer (and possibly benefit less from) externalities.

\section{Explained Variable: Creation of New Export Linkages}

The creation of a new export transaction is measured by a dummy that takes the value 1 if the domestic firms in province $i$ begin exporting product $k$ to country $j$ at time $t+1$ and 0 otherwise. A specific database is constructed that incorporates the set of alternatives faced by each province. For a given province, these alternatives are defined as the product-country pairs for which at least one export start is observed over the 1997-2007 period.

For these province-product-country triads, the dataset is originally a balanced panel from 1997 to 2007 covering 211 countries and 1213 HS4 products. The dataset includes 1,050,516 observations each year, resulting in a total of 11,551,716 (province/product/country/year) observations over the 1997-2007 period. Approximately 11 percent of the observations from the entire database correspond to domestic starts, that is, to provinces where domestic firms do not export product $k$ to country $j$ at time $t$ but do export $k$ to $j$ at time $t+1$.

These domestic starts are the trade flows to be explained. As in Koenig et al. (2010), ceasing and continuing export flows are not included in the study. Given the time span, for a given province-product-country triad, several starts might be observed. For example, the subsequent export statuses 00011001111 become $.001 . .01 \ldots$ in our sample, with 1 denoting positive exports, 0 denoting no exports, and . denoting a missing value. By definition, all of the observations are missing for 1997, the first year in the sample, because the export statuses in 1996 are not observed. Continuing export flows (a 1 preceded by another 1) and ceasing export flows (a 0 preceded by a 1 ) are also coded as a dot because they are excluded from the analysis.

Because the estimations will include province-product-country fixed effects, taking into account a broader definition of the possible exported products or the destination countries would not change the final sample used for the estimations. The behavior of the province-product-country triads for which we observe positive export flows or null export flows every year of the period would be explained by the fixed effect.

Unreported results, available upon request, show that the conclusions are very much the same when the sample is restricted to durable starts, defined as export starts leading to positive export values for at least two consecutive years. This finding suggests that the foreign export spillovers captured by the entire sample are not driven by short-lived transactions. ${ }^{4}$

4. In the case of durable starts, note, however, that because our data are not at the firm level but are aggregated by firm type, it might be the case that the domestic exports that we observe in the two consecutive years emanate from two different domestic firms. 


\section{Empirical Approach}

The creation of a new linkage (product $k /$ country $j$ ) by the domestic firms of province $i$ at year $t+1$ is regressed on our proxy for foreign export spillovers in the previous year $t$ and on various controls (measured in $t$ and in $t-1$ ) following a gravity-type equation. Our empirical equation is thus the following:

$$
\begin{aligned}
\operatorname{Prob}\left(\text { dom. } \text { start }_{i k j, t+1}\right)= & \operatorname{Prob}\left(\alpha \text { foreign_spill } i_{i k j, t}+\beta_{1} Z_{i k j, t}+\beta_{2} Z_{i k j, t-1}+\eta_{i k j}\right. \\
& \left.+\mu_{t+1}+\epsilon_{i k j, t+1}>0\right) .
\end{aligned}
$$

Using a conditional logit estimation, all regressions are estimated including fixed effects at the province-product-destination country level $\eta_{i k j}$. This allows for the consideration of all time-invariant characteristics that can explain the export activities for product $k$ to country $j$ of both domestic and foreign firms in province $i$. Indeed, inward FDI might be attracted to particular provinces due to the presence of local specific advantages for exporting a given product and/or to a given destination. In this case, the estimation would suffer from a reverse causality issue. In particular, the transport infrastructure and endowments of province $i$, the variables that explain the business relationships between province $i$ and country $j$ (distance, migrant networks) and the local comparative advantage of province $i$ for product $k$ are taken into account by $\eta_{i k j}$ as long as they are fixed over time. The year fixed effects $\mu_{t+1}$ are also added to control for aggregate shocks to the Chinese export activities. Given this estimation strategy, foreign export spillovers are identified based on the within (time) dimension of the data. Hence, the time-varying determinants of domestic and foreign firms' exports $Z$ must also be considered.

The conditioning set $Z$ is composed of three categories of variables. First, following the gravity literature, the demand-side determinants of new export linkages are controlled for by the destination country's import value, defined at the four-digit product level taken from the BACI world trade dataset ${ }^{5}$ and the GDP per capita of the importing country. ${ }^{6}$ Second, supply-side determinants are taken into account by introducing proxies for provincial and Chinese comparative advantages and export intensity. In the absence of firm-level data, these controls are crucial to account for the time-varying ability of different provinces to export different products to different countries. Hence, the log of the province total export sales, the province-product export sales, and the China-product export sales in year $t$ are introduced. Because the regression also includes year fixed effects, which account for the evolution of total Chinese exports, controlling for these variables amounts to introducing the elements of a Balassa index of

5. This dataset, which is constructed using COMTRADE original data, provides bilateral trade flows at the six-digit product level (Gaulier and Zignago 2010). BACI is downloadable from http:/www.cepii.fr/ anglaisgraph/bdd/baci.htm (Last access date April 8, 2013).

6. The world countries' GDP per capita are taken from the World Development Indicators database (World Bank). 
"revealed comparative advantage" at the province-product level. The total bilateral exports from province $i$ to country $j$ and the total Chinese bilateral exports to country $j$ are also introduced to control for specific relationships between the province/China and the destination country. This step is important given the use of business and trade agreements by the Chinese authorities to manage their diplomacy. Finally, the province GDP per capita is used to take into account the supply-side determinants of exports such as workers' skills. ${ }^{7}$ Third, to ensure that the decision of domestic firms to start exporting does not capture the intrinsic dynamics of exports at the product level or at the country level, the lag values of Chinese and province $i$ 's exports at the product level and at the destination country level are included, as well as the lag of foreign demand, to control for specific dynamics on the demand side.

Finally, the other export activities undertaken by the domestic firms of province $i$ in year $t$ are controlled for. By construction, because only newly created linkages at the product-country level are considered, there is no export activity by the domestic firms of the province in the previous year for the considered product-country pair. However, the export activities in other products for the same country, in other countries for the same product, and in other products and other countries must be taken into account. Considering these controls ensures that the coefficient for foreign export spillovers will not proxy for spillovers between different domestic firms or for scope economies within the same firm.

Below, the empirical results obtained using this type of specification are shown to hold when controlling for potential remaining endogeneity, by including more demanding fixed effects or using instrumental variables.

Regarding export spillovers, two different proxies are proposed. First, the value of foreign exports is used. However, in only 4.2 percent of the final sample observations do we observe positive exports for the product-country specific spillover variables. Foreign export activities are then decomposed into the mere presence of foreign exporters for a given product-country pair, as measured by a dummy, and the value of their exports. By doing so, it becomes possible to assess whether foreign export spillovers are due to a switch in foreign export activities (from no export to positive exports) or to changes in the scale of exports realized by foreign firms. Disentangling what is due to the scale of foreign export activities from the more general impact of the presence of foreign exporters ${ }^{8}$ is important when the share of observations in which positive foreign export flows are observed is small.

7. The provincial GDP per capita are taken from the China Statistical yearbooks.

8. In contrast, the share of null values for other (more aggregated) foreign export spillovers is very small, suggesting that the issue is restricted to product-country specific spillovers. The values are, respectively, $0,13.4$, and 31.5 percent for other products/countries, same country-other products, and same product-other countries spillovers. In unreported results, we check that the results are unaffected when using the same approach (including both the presence dummy and the value) to study the impact of the other foreign export spillover variables. 


\section{Descriptive Statistics}

Province-product-country triads for which at least one export start is observed over the period are used in the estimation. For these province-product-country triads, the observations originally constitute a balanced panel from 1997 to 2007, covering 211 countries and 1213 HS4 products. As reported in Table 1, the data include 1,050,516 observations each year, resulting in a total of $11,551,716$ (province/product/country/year) observations over the 1997-2007 period. Approximately 32 percent of the observations correspond to strictly positive export flows from domestic firms. As emphasized in Table 2, 1,268,768 observations of the 11,551,716 observations of the entire database correspond to domestic starts, that is, to provinces where domestic firms do not export product $k$ to country $j$ at time $t$ but do export at time $t+1$.

As shown in Table 1, 11.5 percent of the observations in this balanced sample have non-null product-country-specific foreign export flows. The share rises to 26 percent if the sample is restricted to the observations for which domestic firms report positive exports. As emphasized in Table 2, 7.5 percent of domestic starts occurred when foreign firms in the province were exporting the same product to the same country the year before. As indicated in Table A-1 in the Appendix, the proportion is 69.8 percent when considering foreign exports of the same product to other countries and 88.6 percent when considering foreign exports of other products to the same country.

The geographic and sectoral distributions of the new trade linkages established by Chinese domestic firms over the period are described in Table 3. The export starts are quite diversified in terms of destinations. The US is the main destination for new trade linkages over the period, but it only represents 1.8 percent of overall export starts, followed by Hong Kong, South Korea, and Japan, with between 1.6 percent and 1.7 percent of all export starts. However, new transactions are more concentrated in terms of the province of origin, the most dynamic exporters being, not surprisingly, Guangdong (8.5 percent) and Zhejiang (7.5 percent). The export starts are also more concentrated from a sectoral viewpoint: "Nuclear reactors, machinery etc." account for 10.5 percent of new transactions over the period in comparison with 6.6 percent for "Electrical machinery etc." and 4.4 percent for "Articles of iron and steel".

\section{Estimation of Foreign Export Silllovers}

Following Koenig et al. (2010), different types of spillovers are considered. Depending on the type of information needed to successfully enter export markets, the export spillovers could be destination specific, product specific, or both. For a given triad province-product-destination country $i k j$, the spillovers are thus decomposed into four non-overlapping components: product-(HS4) and destination-country-specific (foreign exports from province $i$ of product $k$ to country $j$ ), country-specific (foreign exports from province $i$ of products other 
Ta B LE 1. Summary Statistics on Domestic Exports and Foreign Presence: Number of Observations

\begin{tabular}{|c|c|c|c|c|c|c|c|c|c|c|}
\hline \multirow[b]{3}{*}{ Year } & \multicolumn{3}{|c|}{ Domestic exports $>0$} & \multicolumn{3}{|c|}{ Domestic exports $=0$} & \multicolumn{4}{|c|}{ All } \\
\hline & \multicolumn{2}{|c|}{ Foreign exports } & \multirow{2}{*}{$\begin{array}{c}\text { Share } \\
\text { For. exp. }>0\end{array}$} & \multicolumn{2}{|c|}{ Foreign exports } & \multirow{2}{*}{$\begin{array}{c}\text { Share } \\
\text { For. exp. }>0\end{array}$} & \multicolumn{2}{|c|}{ Foreign exports } & \multirow[b]{2}{*}{ Total } & \multirow{2}{*}{$\begin{array}{c}\text { Share } \\
\text { For. exp. }>\end{array}$} \\
\hline & $=0$ & $>0$ & & $=0$ & $>0$ & & $=0$ & $>0$ & & \\
\hline 1997 & 148,728 & 40,780 & 0.215 & 837,730 & 22,918 & 0.027 & 986,458 & 63,698 & $1,050,516$ & 0.060 \\
\hline 2000 & 205,471 & 59,359 & 0.224 & 757,474 & 27,852 & 0.035 & 962,945 & 87,211 & $1,050,516$ & 0.083 \\
\hline 2003 & 255,308 & 88,998 & 0.258 & 669,855 & 35,995 & 0.051 & 925,163 & 124,993 & $1,050,516$ & 0.119 \\
\hline 2006 & 354,655 & 141,129 & 0.285 & 509,791 & 44,581 & 0.080 & 864,446 & 185,710 & $1,050,516$ & 0.177 \\
\hline Total & $2,730,325$ & 957,461 & 0.260 & $7,493,638$ & 370,292 & 0.047 & 10223963 & $1,327,753$ & $11,551,716$ & 0.115 \\
\hline
\end{tabular}

Source: Chinese customs and authors' calculations. 
Table 2. Summary Statistics on Domestic Starts and Foreign Presence: Number of Observations

\begin{tabular}{|c|c|c|c|c|}
\hline \multirow[b]{3}{*}{ Year } & \multicolumn{4}{|c|}{ Domestic start $=1$} \\
\hline & \multicolumn{2}{|c|}{ Foreign exports } & \multirow[b]{2}{*}{ Total } & \multirow{2}{*}{$\begin{array}{c}\text { Share } \\
\text { For. exp. }>0\end{array}$} \\
\hline & $=0$ & $>0$ & & \\
\hline 1998 & 78,130 & 5,688 & 83,818 & 0.068 \\
\hline 2001 & 100,001 & 7,889 & 107890 & 0.073 \\
\hline 2004 & 136,288 & 11,211 & 147,499 & 0.076 \\
\hline 2007 & 146,317 & 13,001 & 159,318 & 0.082 \\
\hline Total & $1,174,078$ & 94,690 & $1,268,768$ & 0.075 \\
\hline
\end{tabular}

Source: Chinese customs and authors' calculations.

TA B LE 3. Summary Statistics on Domestic Starts: Share in Total Export Starts Over the Period

\begin{tabular}{lr}
\hline Destinations & \\
USA & $1.8 \%$ \\
Hong-Kong & $1.7 \%$ \\
South-Korea & $1.7 \%$ \\
Japan & $1.6 \%$ \\
Malaysia & $1.5 \%$ \\
Provinces & \\
Guangdong & $8.5 \%$ \\
Zhejiang & $7.5 \%$ \\
Shanghai & $7.0 \%$ \\
Jiangsu & $7.0 \%$ \\
Beijing & $6.7 \%$ \\
Sectors (HS2) & \\
Nuclear reactors, machinery et al. & $10.5 \%$ \\
Elect machinery et al. & $6.6 \%$ \\
Art. of iron and steel & $4.4 \%$ \\
Organic chem. & $4.1 \%$ \\
Optical, photo. & $4.0 \%$ \\
\hline
\end{tabular}

Source: Chinese customs and authors' calculations.

than $k$ to country $j$ ), product-specific (foreign exports of product $k$ to countries other than $j$ ), and general spillovers (foreign exports of products other than $k$ to countries other than $j$ ).

The coefficients for the various spillover variables capture the net effect of the positive externalities described above and some possible negative effects, such as the pressure exerted by foreign firms on local labor markets, which might increase wages (as highlighted by Hale and Long, 2011, for skilled workers in China) or congestion effects linked to the saturation of transport infrastructures. 


\section{Nature of Foreign Export Spillovers}

In this section, the value of exports realized by foreign firms is used as a proxy for foreign export spillovers. Because Moulton (1990) has shown that regressing individual variables on aggregate variables can induce a downward bias in the estimation of standard errors, all regressions presented in the paper are clustered at the province level.

When relying on the most aggregated measure of local foreign export activity (all products-all destinations), a negative and weakly significant effect is detected (column 1 of Table 4). This effect might be due to crowding-out effects or to an accounting issue; because total exports in province $i$ in year $t$ are also controlled for, the higher the share of foreign firms in these exports, the less probable the entry of domestic firms into foreign markets the following year. The countryspecific (all products-same destination) and product-specific (same product-all destinations) spillover variables also show a negative sign, but the coefficient is very close to zero and not significant (columns 2 and 3 of Table 4). This is not the case for the most precise measure of foreign spillovers (same product-same destination). Interestingly, the product-country specific spillover variable is positive and significant at the 1 percent confidence level (column 4 of Table 4), indicating that the entry of domestic firms into the export markets for product $k$ and country $j$ in year $t+1$ is positively influenced by the export activities of foreign firms for product $k$ and country $j$ in year $t$.

To further assess the specificity of export spillovers for a given provinceproduct-destination country triad $i k j$, the overall export value of foreign firms from province $i$ is decomposed in column 5 into its four complementary components: exports of the same product $k$ to the same country $j$, exports of the same product $k$ to other countries, exports of other products to the same country $j$, and exports of other products to other countries. The dynamics of the demandside and supply-side determinants of entry into the export markets is also controlled for by introducing the relevant controls in $t-1$. With this specification, the product-country specific spillover measure is the only measure that is positive and significant. When the past export performance of domestic firms in province $i$ is added to neutralize export spillovers between domestic firms and/or scope economies in domestic export activities, the main result holds: the coefficient of foreign product-country specific export spillovers slightly increases to reach 0.023 (column 6 of Table 4).

A series of robustness checks are presented in Table A-2 in the appendix. Excluding successively agricultural products and mining products or focusing exclusively on the manufacturing sector does not affect the results (columns 2 to 4 of Table A-2), suggesting that the previous findings do not simply reflect weather conditions or local natural endowments that could jointly determine foreign and domestic export performance. Dropping the product-country pairs for which China is the main supplier of the destination country (45 percent and 85 percent of the total imports of product $k$ by country $j$ ) also leaves the results 


\begin{tabular}{|c|c|c|c|c|c|c|c|}
\hline & \multirow{3}{*}{$\begin{array}{c}\text { Explained variable } \\
\text { Estimator }\end{array}$} & \multicolumn{6}{|c|}{ Domestic new export link in $t+1$} \\
\hline & & \multicolumn{6}{|c|}{ Conditional logit } \\
\hline & & $(1)$ & $(2)$ & (3) & $(4)$ & $(5)$ & (6) \\
\hline \multirow[t]{7}{*}{ Foreign export spillovers Year $t$} & Ln all products-countries foreign export & $\begin{array}{r}-0.247^{c} \\
(0.137)\end{array}$ & & & & & \\
\hline & Ln same country-all products foreign export & & $\begin{array}{r}-0.004 \\
(0.003)\end{array}$ & & & & \\
\hline & Ln same product-all countries foreign export & & & $\begin{array}{r}-0.002 \\
(0.002)\end{array}$ & & & \\
\hline & Ln same product/country foreign export & & & & $\begin{array}{c}0.021^{a} \\
(0.002)\end{array}$ & $\begin{array}{c}0.021^{a} \\
(0.002)\end{array}$ & $\begin{array}{r}0.023^{a} \\
(0.001)\end{array}$ \\
\hline & Ln other products-same country foreign export & & & & & $\begin{array}{r}-0.003 \\
(0.003)\end{array}$ & $\begin{array}{c}0.001 \\
(0.003)\end{array}$ \\
\hline & Ln other countries-same product foreign export & & & & & $\begin{array}{r}-0.003 \\
(0.002)\end{array}$ & $\begin{array}{c}0.004^{b} \\
(0.002)\end{array}$ \\
\hline & Ln other countries/products foreign export & & & & & $\begin{array}{r}-0.232^{c} \\
(0.131)\end{array}$ & $\begin{array}{r}-0.255 \\
(0.215)\end{array}$ \\
\hline \multirow[t]{2}{*}{ Demand Year $t$} & Ln country-product total imports & $\begin{array}{c}0.081^{a} \\
(0.008)\end{array}$ & $\begin{array}{c}0.081^{a} \\
(0.008)\end{array}$ & $\begin{array}{c}0.081^{a} \\
(0.008)\end{array}$ & $\begin{array}{c}0.080^{a} \\
(0.008)\end{array}$ & $\begin{array}{c}0.025^{a} \\
(0.005)\end{array}$ & $\begin{array}{r}0.025^{a} \\
(0.005)\end{array}$ \\
\hline & Ln country GDP per capita & $\begin{array}{c}0.258^{a} \\
(0.035)\end{array}$ & $\begin{array}{c}0.260^{a} \\
(0.035)\end{array}$ & $\begin{array}{c}0.258^{a} \\
(0.034)\end{array}$ & $\begin{array}{c}0.256^{a} \\
(0.034)\end{array}$ & $\begin{array}{c}0.172^{a} \\
(0.035)\end{array}$ & $\begin{array}{r}0.173^{a} \\
(0.034)\end{array}$ \\
\hline \multirow[t]{6}{*}{ Supply Year $t$} & Ln export province & $\begin{array}{r}0.687^{a} \\
(0.196)\end{array}$ & $\begin{array}{r}0.570^{a} \\
(0.204)\end{array}$ & $\begin{array}{r}0.572^{a} \\
(0.204)\end{array}$ & $\begin{array}{r}0.568^{a} \\
(0.204)\end{array}$ & $\begin{array}{r}0.437^{a} \\
(0.155)\end{array}$ & $\begin{array}{c}0.574 \\
(0.747)\end{array}$ \\
\hline & Ln export province-product & $\begin{array}{c}0.182^{a} \\
(0.007)\end{array}$ & $\begin{array}{c}0.184^{a} \\
(0.007)\end{array}$ & $\begin{array}{c}0.186^{a} \\
(0.007)\end{array}$ & $\begin{array}{c}0.182^{a} \\
(0.007)\end{array}$ & $\begin{array}{c}0.170^{a} \\
(0.007)\end{array}$ & $\begin{array}{r}0.075^{a} \\
(0.010)\end{array}$ \\
\hline & Ln export province-country & $\begin{array}{r}0.147^{a} \\
(0.018)\end{array}$ & $\begin{array}{r}0.151^{a} \\
(0.019)\end{array}$ & $\begin{array}{r}0.148^{a} \\
(0.017)\end{array}$ & $\begin{array}{r}0.147^{a} \\
(0.017)\end{array}$ & $\begin{array}{r}0.140^{a} \\
(0.018)\end{array}$ & $\begin{array}{c}0.065^{b} \\
(0.028)\end{array}$ \\
\hline & Ln export China-product & $0.426^{a}$ & $0.424^{a}$ & $0.425^{a}$ & $0.421^{a}$ & $0.340^{a}$ & $0.331^{a}$ \\
\hline & Ln export China-country & $0.217^{a}$ & $0.217^{a}$ & $0.215^{a}$ & $\begin{array}{r}(0.015) \\
0.215^{a}\end{array}$ & $\begin{array}{r}(0.016) \\
0.173^{a}\end{array}$ & $0.171^{a}$ \\
\hline & & $(0.026)$ & $(0.026)$ & $(0.027)$ & $(0.027)$ & $(0.022)$ & $(0.022)$ \\
\hline
\end{tabular}




\begin{tabular}{|c|c|c|c|c|c|c|c|}
\hline & \multirow{3}{*}{$\begin{array}{c}\text { Explained variable } \\
\text { Estimator }\end{array}$} & \multicolumn{6}{|c|}{ Domestic new export link in $t+1$} \\
\hline & & \multicolumn{6}{|c|}{ Conditional logit } \\
\hline & & (1) & (2) & (3) & (4) & (5) & (6) \\
\hline & Ln province GDP per capita & $\begin{array}{r}-0.413 \\
(0.475)\end{array}$ & $\begin{array}{r}-0.650 \\
(0.509)\end{array}$ & $\begin{array}{l}-0.652 \\
(0.509)\end{array}$ & $\begin{array}{c}-0.651 \\
(0.512)\end{array}$ & $\begin{array}{r}-0.498 \\
(0.460)\end{array}$ & $\begin{array}{r}-0.490 \\
(0.456)\end{array}$ \\
\hline \multirow[t]{6}{*}{ Macro lags Year $t-1$} & Lag Ln country-product total imports & & & & & $\begin{array}{r}0.239^{a} \\
(0.009)\end{array}$ & $\begin{array}{r}0.238^{a} \\
(0.009)\end{array}$ \\
\hline & Lag Ln export province & & & & & $\begin{array}{r}0.285^{c} \\
(0.148)\end{array}$ & $\begin{array}{r}0.275^{c} \\
(0.151)\end{array}$ \\
\hline & Lag Ln export province-product & & & & & $\begin{array}{r}0.027^{a} \\
(0.006)\end{array}$ & $\begin{array}{r}0.028^{a} \\
(0.006)\end{array}$ \\
\hline & Lag Ln export province-country & & & & & $\begin{array}{c}0.019^{c} \\
(0.011)\end{array}$ & $\begin{array}{r}0.019^{c} \\
(0.011)\end{array}$ \\
\hline & Lag Ln export China-product & & & & & $0.080^{a}$ & $0.077^{a}$ \\
\hline & Lag Ln export China-country & & & & & $\begin{array}{c}(0.012) \\
0.037^{b} \\
(0.016)\end{array}$ & $\begin{array}{c}(0.012) \\
0.036^{b} \\
(0.017)\end{array}$ \\
\hline \multirow[t]{7}{*}{ Dom. presence Year $t$} & Ln other countries-same product domestic export & & & & & & $\begin{array}{r}0.098^{a} \\
(0.006)\end{array}$ \\
\hline & Ln other products-same country domestic export & & & & & & $\begin{array}{r}0.074^{a} \\
(0.023)\end{array}$ \\
\hline & Ln other countries/products domestic export & & & & & & $\begin{array}{c}-0.132 \\
(0.626)\end{array}$ \\
\hline & Observations & \multicolumn{6}{|c|}{$4,374,850$} \\
\hline & R-squared (\%) & 12.23 & 12.19 & 12.19 & 12.21 & 12.59 & 12.69 \\
\hline & Fixed effects & \multirow{2}{*}{\multicolumn{6}{|c|}{$\begin{array}{l}\text { Province-product(HS4)-country triad, year } \\
0.219\end{array}$}} \\
\hline & Share of domestic starts & & & & & & \\
\hline
\end{tabular}

Notes: Heteroskedasticity-robust standard errors are reported in parentheses. Standard errors are clustered at the province level. ${ }^{a, b}$ and ${ }^{c}$ indicate significance at the 1 percent, 5 percent and 10 percent confidence levels.

Source: Chinese customs and authors' calculations. 
unchanged (columns 5 and 6). ${ }^{9}$ The top three exporting provinces (Guangdong, Shanghai, and Jiangsu) do not drive the results (column 7). A similar conclusion is obtained when dropping the clothing, textile, and footwear sectors that benefited from dramatic trade liberalization over the period (column 8). Finally, excluding the greater China destinations (Hong Kong, Macao, and Taiwan) to account for round-tripping and the well-known outward-oriented province of Guangdong does not change the conclusions (columns 9 and 10). The results are remarkably stable across samples; foreign export spillovers do not appear to be driven by specific products or specific locations in China.

\section{Endogeneity Issues}

So far, the estimations control for province-product-country fixed effects and for different time-varying dimensions of export performance for domestic and foreign firms in the two years preceding the observation. However, if some shocks affect the capacity of both domestic and foreign firms from province $i$ to export product $k$ to country $j$ and if foreign firms take this new opportunity before domestic firms, our estimation strategy does not completely correct for endogeneity. Three types of shocks can be considered.

Productivity shocks: It might be the case that both foreign and domestic firms from province $i$ at some point experience a productivity shock specific to product $k$ but do not enter the export markets at exactly the same time. This situation would bias the estimation of spillovers. However, this unobserved change in the ability of the foreign and domestic firms of province $i$ to produce and export product $k$ should affect the domestic starts regardless of the destination country. These productivity shocks can thus be controlled for by adding an HS4-province-year fixed effect to the baseline regression. Foreign export spillovers are then identified using heterogeneity across destinations within a given HS4-province-year.

Demand shocks: The preferences of consumers from country $j$ for product $k$ across the different importing sources might evolve differently over time. Controlling for the total imports of product $k$ by country $j$ at time $t$ and $t-1$ does not account for the heterogeneous dynamics of demand in the destination country. If German consumers begin consuming increasing amounts of Chinese trousers at the expense of Vietnamese ones, this shift is not captured by our specification. However, if these types of preference dynamics are at play, it is unlikely that they would differ across Chinese provinces; consumers know whether products are produced in China, but they do not know in which province the products are produced. Consequently, if the preferences of consumers from country $j$ for product $k$ that is produced in China evolve over time, they should do so homogeneously across provinces. The destination country-HS4-year fixed effects should thus control for these demand shocks. Foreign export spillovers would then be

9. The product-level world share of China is computed for the year 1997. 
estimated by comparing, for a given HS4-destination country-year, the timing of the domestic starts across Chinese provinces.

Province-destination country shocks: In the case of bilateral shocks affecting the economic relationships between a province and a destination country (changes in the location of provincial diasporas abroad, province-country economic agreements), the HS4-province-year and the HS4-destination country-year fixed effects will not be sufficient to purge the estimation of export spillovers from endogeneity. The inclusion of province-destination country-year dummies can address this issue.

Province-product-country-year shocks: Finally, it could be the case that unobserved shocks specific to province $i$, product $k$, country $j$, and time $t+1$ bias our results. The addition of the three types of fixed effects proposed earlier would not solve the problem. However, it is not possible to introduce HS4-province-destination country-year fixed effects because such fixed effects would be in the same dimension as the export spillovers. The instrumentation of the spillover variable is thus the only solution. To instrument the exports of product $k$ to country $j$ by foreign firms in province $i$ at time $t$, variables must be identified that can explain foreign exports at time $t$ without being directly correlated with domestic exports at time $t+1$. Good candidates for this purpose are the province-specific FDI policies that are likely to modulate, across Chinese provinces, the consequences of demand shocks that are specific to product $k$ and country $j$. In particular, the Export Processing Zones (EPZ) have been one of the most important components of China's strategy to attract multinationals. Since 1980 , the central government has opened a number of these zones, which offer specific incentives to foreign investors (Fu and Gao 2007). Another manifestation of the efforts of Chinese authorities to attract multinational firms, specifically those producing higher-end variety products, is the proliferation of governmentsponsored high-tech zones (Wang and Wei 2010). ${ }^{10}$ Both types of zones are thus likely to favor exports by foreign firms without directly affecting exports by Chinese firms. Our instrumentation strategy thus relies on the hypothesis that international demand conditions affect foreign firms' exports differently across provinces depending on the presence of these zones. In particular, the impact of a positive demand shock for product $k$ in country $j$ on the foreign firms in province $i$ will be stronger when the number of EPZ and high-tech zones in province $i$ is high. Concretely, the variable used to instrument the export value of foreign firms in province $i$ for a given product-country-year triad kjt is the interaction between demand conditions (import value from the rest of the world) for that country-product-year triad and the number of zones in the province. We use two instruments that rely on the number of EPZs and the number of high-tech zones by province and year, taken from Wang and Wei (2010). Because EPZ and

10. In the rest of the paper, we include in this category the zones identified by Wang and Wei (2010) as "Special Economic Zones", "Economic \& Technological Development Areas", and "High-Technology Industry Development Areas”. 
high-tech zones should not directly affect exports by domestic firms and because the total imports of product $k$ by country $j$ at time $t$ are also introduced as an independent regressor, the instruments proposed are likely to be exogenous.

It is not possible to include the various above-mentioned additional fixed effects or to apply our instrumentation strategy in a conditional logit model. Hence, a linear probability model with adequate fixed effects is used in this section. Our benchmark results (column 6 of Table 4) are first replicated and do not differ significantly in terms of sign, significance, and magnitude between using a conditional logit (column 1 of Table 5 ) or a linear probability model (column 2 of Table 5). In column 2 , the coefficients can be interpreted as marginal effects. A 10 percent increase in the value of exports of product $k$ to country $j$ by foreign firms located in province $i$ at time $t$ increases the probability that the domestic firms in the same province will begin exporting product $k$ to country $j$ at time $t+1$ by 0.07 percentage points. This result is reassuringly close to the result from a conditional logit estimation (0.05 percentage points). ${ }^{11}$ It thus appears reasonable to believe that the results obtained by adding controls or using IV in the linear probability model would provide a similar result if it were possible to use them in a conditional logit specification. The inclusion of province-HS4-year, destination country-HS4-year fixed effects, or province-destination country-year fixed effects does not change the results (columns 3 to 5): the significance and the magnitude of the product and the destination country-specific foreign export spillovers remain unaffected. The ranking of the different types of spillovers also remains qualitatively the same. These results suggest that specific productivity shocks, demand shocks, or provincecountry shocks do not drive the results. The IV estimates are also reassuring (column 6). The first-stage results suggest, as expected, that positive demand shocks result in greater foreign exports in provinces with many EPZs (column 7). The interaction with the number of high-tech zones, however, fails to be significant. The F-test statistic for the inclusion of additional instruments in the firststage regressions is above the rule of thumb value of 10 , suggesting that the instruments are correlated with the endogenous variables and that there is no weak instrument problem (Staiger and Stock 1997). The Hansen test indicates that the overidentifying restriction is not rejected, supporting the validity of the instruments. In the second stage, the coefficient of interest on the spillover variable appears to be greatly increased. However, the standard error also increases, and the Hausman test for the difference between our benchmark and the twostage least-squares estimates suggests that the exogeneity of the spillover variable in column 2 cannot be rejected. Hence, all of these results show that our benchmark specification does not suffer from a major endogeneity issue. For this

11. The marginal impact of a 10 percent increase in the value of foreign exports of product $k$ to country $j$ is equal to $\left(1.1^{0.023}-1\right) \times$ average probability to start exporting $=\left(1.1^{0.023}-1\right) \times 0.219 \approx$ 0.05 percentage points. 
TABLE 5. Impact of Foreign Export Spillovers: Controlling for Endogeneity

\begin{tabular}{|c|c|c|c|c|c|c|c|c|}
\hline & \multirow{3}{*}{$\begin{array}{c}\text { Explained variable } \\
\text { Estimator }\end{array}$} & \multicolumn{7}{|c|}{ Domestic new export link in $t+1$} \\
\hline & & \multirow{2}{*}{$\begin{array}{c}\text { conditional } \\
\text { logit } \\
(1)\end{array}$} & \multicolumn{6}{|c|}{ Linear probability - fixed effects } \\
\hline & & & $(2)$ & (3) & (4) & $(5)$ & $\begin{array}{l}\text { IV } \\
(6)\end{array}$ & $\begin{array}{c}1^{\text {st }} \text { stage } \\
(7)\end{array}$ \\
\hline \multirow[t]{17}{*}{ Foreign Spillovers } & Same product/country foreign export & $\begin{array}{l}0.023^{a} \\
(0.001)\end{array}$ & $\begin{array}{l}0.007^{a} \\
(0.001)\end{array}$ & $\begin{array}{l}0.007^{a} \\
(0.001)\end{array}$ & $\begin{array}{l}0.006^{a} \\
(0.001)\end{array}$ & $\begin{array}{l}0.006^{a} \\
(0.001)\end{array}$ & $\begin{array}{l}0.083^{a} \\
(0.038)\end{array}$ & \\
\hline & Same country-other products foreign export & $\begin{array}{l}0.001 \\
(0.001)\end{array}$ & $\begin{array}{l}-0.001 \\
(0.001)\end{array}$ & $\begin{array}{l}-0.001 \\
(0.001)\end{array}$ & $\begin{array}{l}-0.0012^{b} \\
(0.0005)\end{array}$ & $\begin{array}{l}0.003^{b} \\
(0.002)\end{array}$ & $\begin{array}{l}-0.001 \\
(0.001)\end{array}$ & $\begin{array}{l}-0.006^{a} \\
(0.002)\end{array}$ \\
\hline & Other countries-same product foreign export & $\begin{array}{l}0.004^{b} \\
(0.001)\end{array}$ & $\begin{array}{l}0.001 \\
(0.001)\end{array}$ & $\begin{array}{l}0.004^{a} \\
(0.001)\end{array}$ & $\begin{array}{l}-0.001 \\
(0.001)\end{array}$ & $\begin{array}{l}-0.0005^{b} \\
(0.0002)\end{array}$ & $\begin{array}{l}-0.0007^{c} \\
(0.00004)\end{array}$ & $\begin{array}{l}0.012^{a} \\
(0.011)\end{array}$ \\
\hline & Other countries-products foreign export & $\begin{array}{l}-0.255 \\
(0.215)\end{array}$ & $\begin{array}{l}-0.028 \\
(0.034)\end{array}$ & $\begin{array}{l}0.034 \\
(0.025)\end{array}$ & $\begin{array}{l}-0.037^{c} \\
(0.021)\end{array}$ & $\begin{array}{l}0.153^{c} \\
(0.089)\end{array}$ & $\begin{array}{l}-0.021 \\
(0.031)\end{array}$ & $\begin{array}{l}-0.004 \\
(0.071)\end{array}$ \\
\hline & Country-product-year world imports $\times \#$ EPZ & & & & & & & $\begin{array}{l}0.020^{a} \\
(0.002)\end{array}$ \\
\hline & $\begin{array}{l}\text { Country-product-year world imports } \times \# \\
\text { High-Tech zones }\end{array}$ & & & & & & & -0.004 \\
\hline & & & & & & & & 0.003 \\
\hline & Control for Macro export & yes & yes & yes & yes & yes & yes & yes \\
\hline & Control for Macro export lags & yes & yes & yes & yes & yes & yes & yes \\
\hline & Control for domestic presence & yes & yes & yes & yes & yes & yes & yes \\
\hline & $\begin{array}{l}\text { Control for GDPs } \\
\text { Observations }\end{array}$ & yes & yes & yes & $\begin{array}{l}\text { yes } \\
4,374,850\end{array}$ & yes & yes & yes \\
\hline & Province-product(HS4)-country fixed effects & yes & yes & yes & yes & yes & yes & yes \\
\hline & Year fixed effects & yes & yes & yes & yes & yes & yes & yes \\
\hline & Province-product-year fixed effects & no & no & yes & no & no & no & no \\
\hline & Country-product-year fixed effects & no & no & no & yes & no & no & no \\
\hline & Province-country-year fixed effects & no & no & no & yes & no & no & no \\
\hline & R-squared $(\%)$ & 12.7 & 8.9 & 12.7 & 12.1 & 6.6 & 2.01 & 2.60 \\
\hline
\end{tabular}


F-test of excluded instruments

Kleibergen-Paap F-stat

Weak Cragg Donald F-test

Hansen overid test

Endogeneity

$$
\mathrm{p} \text {-value }
$$

Notes: Standard errors are clustered at the province level. ${ }^{a, b}$ and ${ }^{c}$ indicate significance at the 1 percent, 5 percent and 10 percent confidence levels. In column 6, we instrument the product-country specific spillovers indicator (Same product/country foreign export) by the interactions of the country-product-year total import value with the number of EPZs and the number of High-Techn zones in the province-year taken from Wei and Wang (2010).

Source: Chinese customs and authors' calculations. 
reason, the conditional logit specification with province-product-country fixed effects is maintained as the preferred specification for the remainder of the paper.

\section{Specification of Spillovers}

In this subsection, the appropriate method of modeling foreign export spillovers and the role of spatial proximity are discussed.

Two strategies are adopted to address the high number of zero foreign trade flows in our sample.

First, the sample is restricted to observations with a non-zero foreign presence for product $k$ and country $j$ in year $t$ (column 2 of Table 6). In this subsample, the average probability of new linkage creation by domestic firms increases from 21.9 percent to 38 percent (as reported at the bottom of the columns). Furthermore, the size of the coefficient increases and is now equal to 0.043 , compared to the benchmark results (column 1 of Table 6). In column 3, the sample is restricted to province/product/country triads for which positive foreign exports are observed in 1997, the first year of the sample). Overall, despite the reduction in the number of observations (100,442 in column 2 and 66,585 in column 3), the positive and significant impact of the product-country specific spillover variable is confirmed.

The second method to address the zero foreign export flows, which is used in the remainder of the paper, is to conserve the full sample and to decompose foreign export activities into the presence of foreign exporters for a given product-country pair, as measured by a dummy, and the value of their exports. Note that this decomposition of foreign exports into the presence of foreign exporters and the value of foreign exports is a way to describe the shape of export spillovers: are spillovers log-linear with respect to the scale of foreign export activities, or is there a discontinuity in the impact of foreign exporters that is linked to their sole presence? The results show that, on average, both margins of spillovers have a positive impact on domestic starts (column 4). This specification does not affect our results for the other dimensions of foreign export activities.

Finally, the spatial dimension of foreign export spillovers has been overlooked so far. Some Chinese provinces might be very large, and the interpretation of the results obtained in terms of spillovers implies some geographic proximity. A first answer to this issue is that although the surface area of some provinces (especially those in the western part of China) is rather large, the economic activity is very concentrated.

The data for 2000 indicate that roughly one-third of industrial production is generated in the capital cities of these provinces, this figure being as high as 37 percent in the province of Gansu, 45 percent in Shaanxi and 49 percent in Heilongjiang. Hence, the actual internal distance between economic players is much smaller than the geographic size of the provinces suggests. This feature is also true for the smaller provinces. For example, in the coastal province of Jilin, 46 percent of the industrial activity takes place in the capital city. 
TAвLE 6. Specification on Foreign Export Spillovers

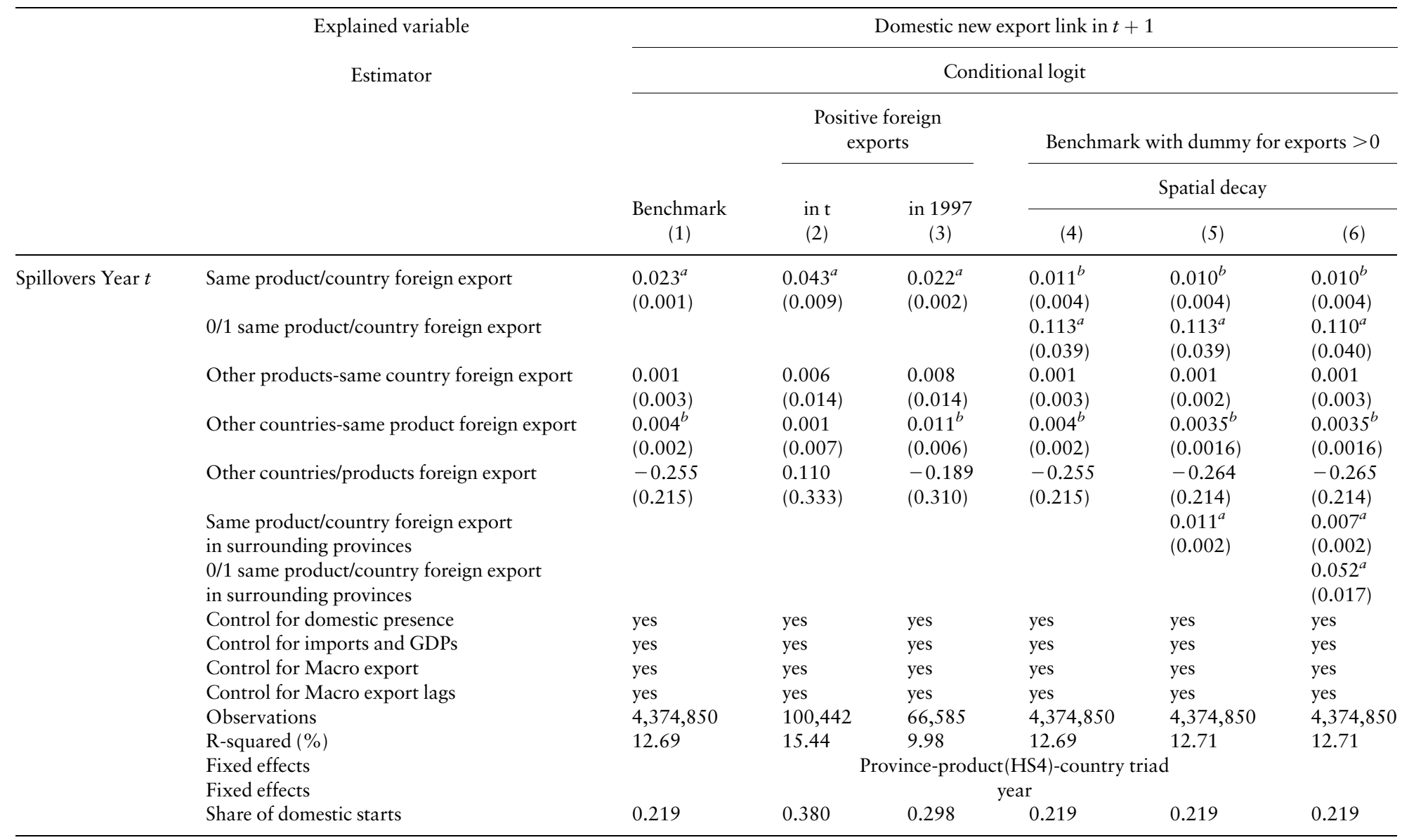

Notes: Heteroskedasticity-robust standard errors are reported in parentheses. Standard errors are clustered at the province level. ${ }^{a, b}$ and ${ }^{c}$ indicate significance at the 1 percent, 5 percent and 10 percent confidence levels.

Source: Chinese customs and authors' calculations. 
We propose a formal test of the "localized" nature of the foreign export spillovers captured so far, introducing exports of product $k$ to country $j$ realized by the foreign firms located in provinces that are contiguous to province $i$ (columns 5 and 6). A positive impact is found for both the presence and the value of foreign exports in the surrounding provinces, but it is clearly lower in magnitude than the effect of exports realized by the foreign firms located in province $i$. Moreover, the impact of foreign exports from province $i$ does not appear to be affected by the inclusion of exports in the contiguous provinces. These results indicate a spatial decay of the effect of foreign exports on domestic starts, which is entirely coherent with the interpretation of our results in terms of spillovers. In a companion paper (Mayneris and Poncet 2013), foreign export spillovers are shown to be stronger for more difficult export markets (markets with tougher administrative procedures on imports or a lower quality of institutions, as measured by the ICRG index). This result is again coherent with the idea that the positive association measured between domestic starts and foreign exports is due to spillovers.

\section{Ordinary versus Processing Trade}

One remaining question is whether the results hold when accounting for the important role of processing trade. Indeed, because the firms engaged in processing trade "simply" import inputs to re-export a transformed product, they might be less embedded in their local environment and consequently generate fewer externalities. In Table 7, the two trade regimes (ordinary and processing) are thus considered separately. All of the regressions are estimated with the conditional logit estimator.

In unreported regressions, it is verified that endogeneity is not an issue in this case, relying on the same instrumentation strategy as before. Four instruments must be found to instrument the four spillover variables (the foreign export value and the foreign export presence for both processing and ordinary trade). The interactions of the country-product-year import value from the rest of the world and the yearly growth-rate of these imports with the number of EPZs and with the number of other special zones in the province-year are used. The first-stage F-tests of the excluded instruments of these unreported regressions, presented at the bottom of Table 7, show that the instruments correctly explain potentially endogenous variables. In all cases, the Hausman test shows that the benchmark regression is not significantly different from the two-stage least-squares estimates. Exogeneity cannot be rejected, so the conditional logit estimations are preferred.

First, to identify whether export spillovers affect the creation of new linkages differently depending on the trade regime used by domestic firms, ordinary (ODT) export linkage creation and processing (PCS) export linkage creation are studied separately.

Interestingly, the results for domestic starts in ordinary trade activities are virtually similar to those obtained when considering all export flows, suggesting that export spillovers primarily apply to the ordinary export activities of 
Table 7. Ordinary Versus Processing Trade

\begin{tabular}{|c|c|c|c|c|c|c|c|}
\hline & \multirow{4}{*}{$\begin{array}{c}\text { Explained variable } \\
\text { Estimator }\end{array}$} & \multicolumn{6}{|c|}{ Domestic new export link in $\mathrm{t}+1$} \\
\hline & & \multicolumn{6}{|c|}{ Conditional logit } \\
\hline & & \multicolumn{2}{|c|}{ Ordinary } & \multicolumn{2}{|c|}{ Processing } & \multicolumn{2}{|c|}{ Ordinary } \\
\hline & & (1) & $(2)$ & (3) & (4) & $(5)$ & (6) \\
\hline \multirow[t]{6}{*}{ Foreign Spillovers } & Same product/country foreign export & $\begin{array}{c}0.011^{b} \\
(0.004)\end{array}$ & $\begin{array}{c}0.011^{b} \\
(0.004)\end{array}$ & $\begin{array}{c}0.013 \\
(0.008)\end{array}$ & $\begin{array}{c}0.013 \\
(0.008)\end{array}$ & & \\
\hline & $0 / 1$ same product/country foreign export & $0.105^{a}$ & $0.104^{a}$ & $0.156^{c}$ & $0.155^{c}$ & & \\
\hline & Total foreign export & $\begin{array}{c}(0.042) \\
-0.289 \\
(0.216)\end{array}$ & $(0.042)$ & $\begin{array}{c}(0.088) \\
-0.350 \\
(0.347)\end{array}$ & $(0.088)$ & & \\
\hline & Other products-same country foreign export & & $\begin{array}{c}-0.0001 \\
(0.003)\end{array}$ & & $\begin{array}{c}0.008 \\
(0.010)\end{array}$ & & \\
\hline & Other countries-same product foreign export & & $\begin{array}{r}0.003^{b} \\
(0.002)\end{array}$ & & $\begin{array}{r}0.008^{c} \\
(0.004)\end{array}$ & & \\
\hline & Other countries/products foreign export & & $\begin{array}{c}-0.288 \\
(0.209)\end{array}$ & & $\begin{array}{c}-0.343 \\
(0.352)\end{array}$ & & \\
\hline \multirow[t]{6}{*}{ Foreign ODT Spillovers } & Same product/country ODT foreign export & & & & & $\begin{array}{r}0.017^{a} \\
(0.003)\end{array}$ & $\begin{array}{r}0.017^{a} \\
(0.003)\end{array}$ \\
\hline & 0/1 same product/country ODT foreign export & & & & & $\begin{array}{r}0.064^{b} \\
(0.027)\end{array}$ & $\begin{array}{r}0.062^{b} \\
(0.027)\end{array}$ \\
\hline & Total ODT foreign export & & & & & $\begin{array}{c}0.097 \\
(0.112)\end{array}$ & \\
\hline & Other products-same country ODT foreign export & & & & & & $\begin{array}{c}0.003 \\
(0.002)\end{array}$ \\
\hline & Other countries-same product ODT foreign export & & & & & & $\begin{array}{c}0.009^{b} \\
(0.002)\end{array}$ \\
\hline & Other countries/products ODT foreign export & & & & & & $\begin{array}{c}0.082 \\
(0.110)\end{array}$ \\
\hline \multirow[t]{5}{*}{ Foreign PCS Spillovers } & Same product/country PCS foreign export & & & & & $\begin{array}{c}0.002 \\
(0.007)\end{array}$ & $\begin{array}{c}0.002 \\
(0.007)\end{array}$ \\
\hline & 0/1 same product/country PCS foreign export & & & & & $\begin{array}{r}0.105^{c} \\
(0.056)\end{array}$ & $\begin{array}{c}0.098^{c} \\
(0.056)\end{array}$ \\
\hline & Total PCS foreign export & & & & & $\begin{array}{c}-0.001 \\
(0.068)\end{array}$ & \\
\hline & Other products-same country PCS foreign export & & & & & & $\begin{array}{r}-0.002 \\
(0.002)\end{array}$ \\
\hline & Other countries-same product PCS foreign export & & & & & & $0.004^{b}$ \\
\hline
\end{tabular}




\begin{tabular}{ccc}
\hline & Conditional logit \\
\hline Ordinary & Processing & Ordinary \\
\hline
\end{tabular}

(1)

(2)

(3)

(4)

(5)

(6)

Other countries/products PCS foreign export

Control for domestic presence

Control for imports and GDPs

Control for Macro export

Control for Macro export lags

Observations

R-squared (\%)

Fixed effects

Fixed effects

Share of ODT domestic starts

Tests IV

F-test of excluded instruments ${ }^{i}$

$\begin{array}{lc} & \\ \text { yes } & \text { yes } \\ \text { yes } & \text { yes } \\ \text { yes } & \text { yes } \\ \text { yes } & \text { yes } \\ & 4,161,535 \\ 12.48 & 12.48\end{array}$

yes
yes
yes
yes

Province-product(HS4)-country triad

\begin{tabular}{|c|c|}
\hline & $\begin{array}{c}(0.002) \\
-0.007 \\
(0.068)\end{array}$ \\
\hline yes & yes \\
\hline yes & yes \\
\hline yes & yes \\
\hline yes & yes \\
\hline \multicolumn{2}{|c|}{$4,161,535$} \\
\hline 12.52 & 12.54 \\
\hline
\end{tabular}

Hansen overid test
p-value
Endogeneity test
p-value

\subsection{7}

$20.35^{a}$

$18.25^{a}$

0.217
$21.44^{a}$
$19.44^{a}$

year

$\begin{array}{rr} & \text { year } \\ 0.184 & 0.184 \\ 99.67^{a} & 113.60^{a} \\ 70.17^{a} & 77.36^{a}\end{array}$

0.217

$12.17^{a}$

$11.62^{a}$

$\begin{array}{ll}1.53 & 1.49 \\ 0.46 & 0.47 \\ 3.41 & 3.40 \\ 0.18 & 0.18\end{array}$

$\begin{array}{ll}1.45 & 1.19 \\ 0.56 & 0.55 \\ 4.30 & 4.41 \\ 0.12 & 0.11\end{array}$

n.a.

$\begin{array}{lllll}3.40 & 4.30 & 4.41 & 5.17 & 5.41 \\ 0.18 & 0.12 & 0.11 & 0.24 & 0.25\end{array}$

Notes: Heteroskedasticity-robust standard errors are reported in parentheses. Standard errors are clustered at the province level. ${ }^{a, b}$ and ${ }^{c}$ indicate significance at the 1 percent, 5 percent and 10 percent confidence levels.

${ }^{i}$ The test statistics correspond to results from linear probability estimates instrumenting the foreign spillovers with the interactions of the country-product-year import value from the rest of the world and of the yearly growth rate of these imports with the number of EPZs and the number of High-Technology zones in the province-year, respectively. The instrumented variables are same product/country foreign export and $0 / 1$ same product/ country foreign export in columns 1 and 2, same product/country ODT foreign export and 0/1 same product/country ODT foreign export in columns 3 and 4 , and same product/country foreign ODT export, same product/country foreign PCS export, 0/1 same product/country ODT foreign export and 0/1 same product/country PCS foreign export in columns 5 and 6. In these two latter regressions, the model is exactly identified so that the Hansen overidentification test cannot be computed.

Source: Chinese customs and authors' calculations. 
domestic firms (columns 1 and 2). Only in that case are both the presence of foreign exporters and their export value statistically and economically significant. In contrast, when the domestic starts are restricted to the processing trade, foreign export activities have an almost insignificant predictive power for the likelihood that domestic firms create new trade linkages (columns 3 and 4); the dummy is only significant at the 10 percent level, whereas the coefficient for the value of exports is not significant at all. Moreover, the processing trade appears to be a marginal trade regime for domestic firms compared to ordinary trade (289,940 observations for the former and 4,161,535 observations for the latter).

When focusing on the export starts for domestic firms engaged in ordinary trade and decomposing foreign export spillovers into the two trade regimes (ordinary and processing), the results suggest that foreign export spillovers primarily derive from the ordinary export activities of foreign firms (columns 5 and 6). For this latter trade regime, the presence of foreign exporters and the size of their export flows both have a positive impact on export starts by domestic firms. In contrast, in the case of foreign processing activities, the dummy is significant at the 10 percent confidence level only, whereas the value of exports has no significant impact. Unreported robustness checks show that these findings are not sensitive to the size of the initial export flow or to its duration. The results remain qualitatively the same for ODT, but both the dummy and the value of exports become insignificant for processing foreign activities in these checks. ${ }^{12}$ These results are consistent with previous findings on the heterogeneous impact of export upgrading depending on trade type. Jarreau and Poncet (2012) show, for example, that the sophistication of foreign exports has no impact on the provincial GDP per capita growth; thus, they argue that processing export performance must not be taken as a signal of the process of technological adoption in China but rather as an artifact of China's participation in the increasing fragmentation of production processes. Processing exports may emanate from foreign firms involved in export-platform FDI. These results on very weak or null export spillovers from processing trade activities are reminiscent of the results obtained by Ruane and Sutherland (2005) for Ireland. ${ }^{13}$

\section{How Large Are Foreign Export Spillovers in China?}

Several thought experiments can provide an idea of the magnitude of the foreign export spillovers measured so far.

12. We thank an anonymous referee for this suggestion. Our primary finding remains the same when we run the regressions on durable starts (i.e., entries in a given market for at least two consecutive years) and when we focus on domestic export starts for which the export value is above a minimum value. We use two alternative thresholds that correspond to the bottom decile and the bottom quartile of the export value of new export flows.

13. Note that in 1998, US multinationals, for which the export platform is a crucial motivation to invest in Ireland, represented 80 percent of foreign firms' manufacturing exports originating from Ireland. A total of 96.4 percent of their turnover was exported. The export activities of US firms in Ireland thus resemble a type of processing trade. 
Ta ble 8. Marginal Impact in Percentage Point - Summary

\begin{tabular}{lcr}
\hline & All sample & ODT \\
& Tab. 6 & Tab. 7 \\
& Col. 4 & Col. 6 \\
\hline Foreign presence perse & 2.62 & 1.39 \\
Foreign exports value & 0.04 & 0.04 \\
\hline
\end{tabular}

Note: Figures correspond to the increase in the average probability that domestic firms start exporting in a product/country pair when foreign firms' exports are positive for this product/country pair (first row) and when foreign firms' exports rise by 10 percent (second row).

Source: Authors' calculations.

Consider first a province where there are no firms, either foreign or domestic, exporting product $k$ to country $j$ at year $t$ and another province where there are foreign firms exporting product $k$ to country $j$, but in negligible quantities. As measured in column 4 of Table 6, the sole presence of foreign exporting firms increases the probability that domestic firms will begin exporting product $k$ to country $j$ in $t+1$ by 11.96 percent in the latter province compared to the former. ${ }^{14}$ Considering the average probability of starting to export in the sample, equal to 21.9 percent, as a reference, the presence of foreign firms exporting product $k$ to country $j$ increases the average probability that domestic firms in the province will start exporting the same product to the same country in $t+1$ by 2.62 percentage points. It is true that only 7.5 percent of domestic starts are associated with foreign exports for the same product-country pair as the year before. However, the marginal impact of this presence is large. Indeed, the impact of the presence of foreign exports of product $k$ to country $j$ at time $t$ is more than seven times greater than the effect of a 10 percent increase in the GDP per capita in the destination country at time $t$ and more than five times greater than the effect of a 10 percent increase in total imports of product $k$ by country $j$ in time $t-1$ (column 6 of Table 4). ${ }^{15}$

As seen in Table 8, the marginal impact of the value of foreign exports is, in contrast, much more modest because a 10 percent increase in the value of the foreign exports of product $k$ to country $j$ increases the probability that domestic firms will start exporting the same product to the same country by 0.1 percent (i.e., by 0.02 percentage points). ${ }^{16}$

Ultimately, focusing on ordinary trade activities for both foreign and domestic firms, the presence per se of foreign firms exporting product $k$ to country $j$

14. Given the form of the logistic function, the increase in probability generated by the sole presence of foreign firms exporting product $k$ to country $j$ is equal to [ $\left.\mathrm{e}^{0.113}-1\right]$ percent.

15. The marginal impact of a 10 percent increase in GDP per capita for the destination country is equal to $\left(1.1^{0.173}-1\right) \approx 1.66$ percent, whereas the marginal impact of a 10 percent increase in the product-destination country demand in $t-1$ is equal to $\left(1.1^{0.238}-1\right) \approx 2.29$ percent.

16. If we consider a reference value $\bar{x}$ for variable $x$, the increase in probability generated by a 10 percent increase in $x$ is equal to $\left(1.1^{\beta_{x}}-1\right) ; \beta_{x}$ is the coefficient of $x$. The increase expressed in percentage points of probability is equal to $\left(1.1^{\beta_{x}}-1\right) P_{\bar{x}}$. 
increases the average probability that domestic firms in the same province will start exporting this product to this country by 1.39 percentage points. ${ }^{17}$ This effect is almost four times greater than the effect of a 10 percent increase in the GDP per capita of the destination country and three times greater than the impact of a 10 percent increase in the product-destination country total imports. A 10 percent increase in the value of foreign exports increases the average probability that domestic firms will start exporting by 0.04 percentage points. ${ }^{18}$

\section{CONCLUSION}

Using panel data from Chinese customs for the 1997-2007 period, domestic firms' capacity to start exporting new varieties to new markets is shown to respond positively to the export activity of neighboring foreign firms. The results are very robust to the introduction of different sets of fixed effects and to instrumentation strategies that control for the endogeneity of foreign exports. Weak or no foreign export spillovers are detected when other dimensions of the export activities of foreign firms are considered (other destination countries, other products). This result is coherent with previous results obtained by Koenig et al. (2010) for France and indicates that externalities in terms of exports operate at a very detailed level of activity. Foreign export spillovers are also found to emanate primarily from ordinary trade activities and benefit the ordinary export starts of domestic firms.

These results have several implications. Over the past decade, the tremendous growth of Chinese exports has often been seen as inevitable due to the cost advantage of Chinese firms. Our results emphasize that entering export markets remains costly for Chinese firms, and we show that foreign firm export activities might help to reduce this entry cost. Hence, even for a country such as China, there is space for initiatives from policy-makers that favor the diffusion of best practices regarding export experience, although the type of information to be diffused is very detailed and specific. Moreover, our findings suggest that foreign firms should be sufficiently embedded in their local environments to generate spillovers because only limited spillovers are measured for foreign processing activities. This result invites caution about the gains expected for domestic exporters from an internationalization strategy based on special economic zones, as these zones primarily attract foreign firms involved in export-platform FDI.

17. This figure corresponds to $\left[\mathrm{e}^{0.062}-1\right] \times 0.217$ from column 6 of Table 7 .

18. This figure corresponds to $\left[1.1^{0.017}-1\right] \times 0.217$ from column 6 of Table 7 . 


\section{APPENDix}

TA B be A-1. Summary Statistics on Domestic Starts and Foreign Presence Nature

\begin{tabular}{|c|c|c|c|c|c|c|c|c|c|c|}
\hline \multirow[b]{4}{*}{ Year } & \multicolumn{5}{|c|}{ Domestic start $=1$} & \multicolumn{5}{|c|}{ Domestic start $=0$} \\
\hline & \multirow[b]{3}{*}{ Total } & \multicolumn{4}{|c|}{ Foreign Exports $>0$} & \multirow[b]{3}{*}{ Total } & \multicolumn{4}{|c|}{ Foreign Exports $>0$} \\
\hline & & \multicolumn{2}{|c|}{ Same product } & \multicolumn{2}{|c|}{ Other products } & & \multicolumn{2}{|c|}{ Same product } & \multicolumn{2}{|c|}{ Other products } \\
\hline & & $\begin{array}{l}\text { Same } \\
\text { country }\end{array}$ & $\begin{array}{c}\text { Other } \\
\text { countries }\end{array}$ & $\begin{array}{l}\text { Same } \\
\text { country }\end{array}$ & $\begin{array}{l}\text { Other } \\
\text { countries }\end{array}$ & & $\begin{array}{l}\text { Same } \\
\text { country }\end{array}$ & $\begin{array}{l}\text { Other } \\
\text { countries }\end{array}$ & $\begin{array}{l}\text { Same } \\
\text { country }\end{array}$ & $\begin{array}{c}\text { Other } \\
\text { countries }\end{array}$ \\
\hline 1997 & 83818 & 5688 & 55047 & 71753 & 83818 & 776830 & 17230 & 444238 & 581812 & 776830 \\
\hline 2006 & 159318 & 13001 & 118686 & 146838 & 159318 & 395054 & 31580 & 250577 & 358320 & 395054 \\
\hline Total & 1268768 & 94690 & 885055 & 1123626 & 1268768 & 6060088 & 226741 & 3674106 & 4956347 & 6060088 \\
\hline Share (\%) & & 7.5 & 69.8 & 88.6 & 100 & & 3.7 & 60.6 & 81.8 & 100 \\
\hline
\end{tabular}

Source: Chinese customs and authors' calculations. 
TAв в E A-2. Impact of Foreign Export Spillovers: Sample Checks

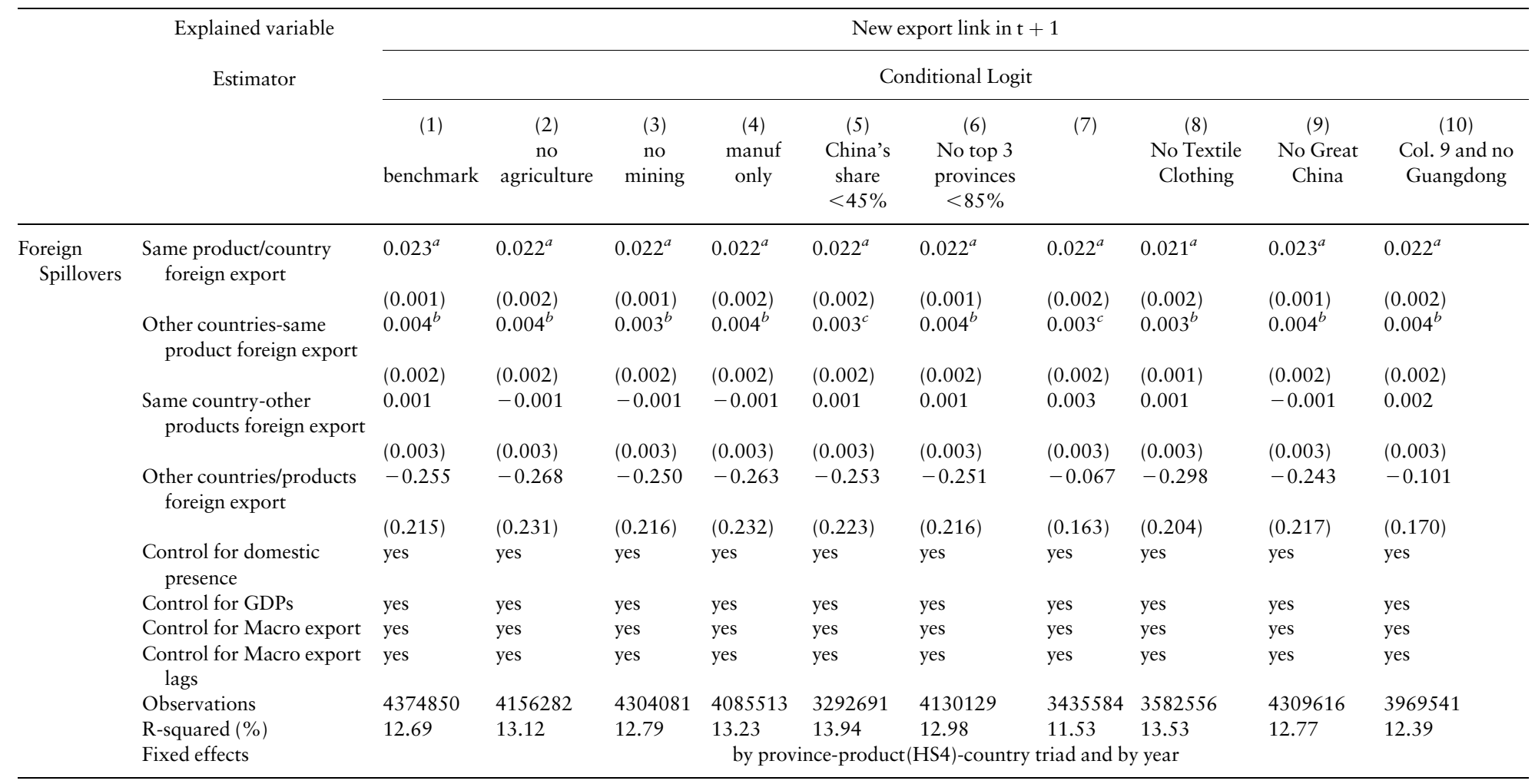

Notes: Heteroskedasticity-robust standard errors are reported in parentheses. Standard errors are clustered at the province level. ${ }^{a, b}$ and ${ }^{c}$ indicate significance at the 1 percent, 5 percent and 10 percent confidence level.

Source: Chinese customs and authors' calculations. 


\section{References}

Aitken, B., G. Hanson, and A. Harrison. 1997. "Spillovers, Foreign Investment, and Export Behavior." Journal of International Economics 43: 103-32.

Amiti, M., and C. Freund. 2010. “An Anatomy of China's Export Growth.” In R. Feenstra and S.-J. Wei, eds., China’s Growing Role in World Trade. Chicago, IL: University of Chicago Press.

Barrios, S., H. Gorg, and E. Strobl. 2003. "Explaining Firms' Export Behaviour: R\&D, Spillovers and the Destination Market." Oxford Bulletin of Economics and Statistics 65 (4): 475-96.

Bernard, A. B., and J. B. Jensen. 2004. "Why Some Firms Export." The Review of Economics and Statistics 86 (2): 561-69.

Chen, H., and D. Swenson. Forthcoming. "Multinational Exposure and the Quality of New Chinese Exports." Oxford Bulletin of Economics and Statistics.

China Statistical Yearbook. 2008. Central, Hong Kong: China Statistics Press.

Feenstra, R., and G. Hanson. 2005. "Ownership and Control in Outsourcing to China: Estimating the Property-Rights Theory of the Firm.” The Quarterly Journal of Economics 120(2): 729-61.

Fu, X., and Y. Gao. 2007. "Export Processing Zones in China: A Survey.” Geneva, Switzerland: International Labour Office.

Gaulier, G., and S. Zignago. 2010. "BACI: A World Database of International Trade at the Product Level, The 1994-2007 Version.” CEPII Working Paper 2010-23. Paris, France.

Hale, G., and C. Long. 2011. "Did Foreign Direct Investment Put an Upward Pressure on Wages in China?.” IMF Economic Review 59: 404-30.

Harding, T., and B. Smarzynska Javorcik. 2012. "FDI and Export Upgrading." Review of Economics and Statistics 94 (4): 964-80.

Jarreau, J., and S. Poncet. 2012. "Export Sophistication and Economic Growth: Evidence from China." Journal of Development Economics 97: 281-92.

Kemme, D., D. Mukherjee, and A. Nikolsko-Rzhevskyy. 2009. "Foreign Direct Investment and Export Performance in Emerging Economies: Evidence from Indian IT Firms.” Mimeo.

Kneller, R., and M. Pisu. 2007. "Industrial Linkages and Export Spillovers from FDI." The World Economy 30 (1): 105-34.

Koenig, P. 2009. “Agglomeration and the Export Decisions of French Firms." Journal of Urban Economics 66 (3): 186-95.

Koenig, P., F. Mayneris, and S. Poncet. 2010. “Local Export Spillovers in France.” European Economic Review 54: 622-41.

Krautheim, S. 2012. "Gravity and Information: Heterogenous Firms, Exporter Networks and the 'Distance Puzzle.'” Journal of International Economics 87: 27-35.

Ma, A. 2006. "Export Spillovers to Chinese Firms: Evidence from Provincial Data.” Journal of Chinese Economic and Business Studies 4(2): 127-49.

Mayer, T., and G.I.P. Ottaviano. 2008. “The Happy-few: The Internationalisation of European Firms.” Intereconomics: Review of European Economic Policy 43(3): 135-48.

Mayneris, F., and S. Poncet. Forthcoming. "Heterogeneous Export Spillovers to Chinese Domestic Firms: The Role of the Difficulty to Enter the Destination Market.” In S. Beugelsdijk, S. Brakman, H. van Ees, and H. Garretsen, eds., Firms in the International Economy: Closing the Gap between InternationalEconomics and International Business. Cambridge, MA: MIT Press.

Melitz, M. 2003. "The Impact of Trade on Intra-Industry Reallocations and Aggregate Industry Productivity." Econometrica 71 (6): 1695-725.

Melitz, M., and G.I.P. Ottaviano. 2008. "Market Size, Trade and Productivity.” The Review of Economic Studies 75 (1): 295-316.

Moulton, B. R.1990. "An Illustration of a Pitfall in Estimating the Effects of Aggregate Variables on Micro Unit.” The Review of Economics and Statistics 72 (2): 334-38. 
Ruane, F., and J. Sutherland. 2005. "Foreign Direct Investment and Export Spillovers: How Do Export Platforms Fare?" IIIS Discussion Paper 58. Dublin, Ireland.

Staiger, D., and J. H. Srock. 1997. "Instrumental Variables Regression with Weak Instruments." Econometrica 65 (3): 557-86.

Swenson, D. 2008. "Multinationals and the Creation of Chinese Trade Linkages." Canadian Journal of Economics 41 (2): 596-618.

Xu, B., and J. Lu. 2009. "Foreign Direct Investment, Processing Trade, and the Sophistication of China's Exports." China Economic Review 20: 425-39.

Wang, Z., and Wei S-J. 2010. "What Accounts for the Rising Sophistication of China's Exports?" In R. Feenstra, and S.-J. Wei, eds., China's Growing Role in World Trade. Chicago, IL: University of Chicago Press. 